UDC: 811.111'255.4:821 https://doi.org/10.22190/JTESAP2003201R

\title{
MODELLING ESP TEACHER IDENTITY IN UKRAINIAN TERTIARY EDUCATION
}

\author{
Maryna Rebenko \\ Foreign Languages for Mathematical Faculties Department, Institute of Philology, Taras Shevchenko National \\ University of Kyiv, Ukraine \\ E-mail: m.rebenko@knu.ua
}

\begin{abstract}
In an attempt to leverage knowledge in an ESP classroom, some university teachers find not much support from the university staff and administration in Ukraine. Yet, it hardly restrains ESP teachers to eagerly develop and construe their professional identity aimed at equipping students with employability literacy skills. A two-stage survey of three different groups of respondents was conducted at Taras Shevchenko University of Kyiv, Ukraine. The findings on the open-ended questionnaire allowed designing a rank of identity constituents, which appeared to be different in research groups' perceptions. While both language and subject teachers valued "individual features" as the most significant and "work experience" as the least, the students correspondingly ranked the other categories "professional knowledge" and "foreign language competence". Within the close-ended questionnaire dataset, these discrepancies vanished. All research groups agreed on the model of "ideal" ESP teacher identity as a combination of significantly ranking categories: "methods of teaching" $\rightarrow$ "professional knowledge" $\rightarrow$ "individual features" $\rightarrow$ "foreign language competence" $\rightarrow$ "work experience". The "professional knowledge" category was estimated twice as significant as the "work experience" domain. The research results are consistent with the recent studies on teacher identity simulation. New was ranking the ESP teacher identity model on constituents' significance based on opinions of three different social groups - students, language teachers, and subject teachers. The worked-out model could remedy ESP teacher identity ambiguity due to approach fruitfulness.
\end{abstract}

Key words: ESP teacher, identity model, questionnaire, identity constituents ranking

\section{INTRODUCTION}

In the Ukrainian tertiary environment, similar to Asian policies (Cheng \& Anthony, 2014), the Bologna reform pushed internalization of social, economic, and academic contexts, and initiated ESP programs' implementation as one of the most fruitful facilitators of this process.

Identity formation of an ESP teacher has become a globally relevant and highly regarded topic. The ongoing curriculum reform of foreign language (FL) teaching in Ukrainian tertiary institutions as a whole and ESP, in particular, has challenged the ESP teacher identity formation due to pushing FL teachers to make a shift in their educational priorities. Such teachers are bound to acquire "skills beyond their primary FL teaching expertise" (Tao \& Gao, 2018) as a key path to meet their audience expectations. Unfortunately, as Tao and Gao have stated (2018), it is not a rare case when "the marginalized status of ESP", imposed by the

Submitted July $25^{\text {th }}, 2020$, accepted for publication October $8^{\text {th }}, 2020$ 
corresponding institution, makes this process less successful. For instance, at Taras Shevchenko National University of Kyiv ESP courses at all non-philological faculties are optional, and students attend them less in comparison to the compulsory General English (GE) courses at linguistics departments. It also occurs that ESP students anticipate immersing themselves into a job-related classroom atmosphere, while their teachers struggle to overcome "subject-matter knowledge gaps" (Wu \& Badger, 2009). On the other hand, linguistics department staff could consider ESP courses as a "threat" (Bolton \& Kuteeva, 2012; Long \& Uzcinski, 2012; Sánchez-López, et al, 2014). One of the keynote speakers at the $4^{\text {th }}$ International Conference on ESP, LSP, GE in Serbia (July 17-19, 2020) Dr. Mary Risner (University of Florida, USA) correspondingly commented on a similar feeling of competition among traditional literature faculties and ESP departments across the US regarding LSP faculty interactions. In Risner's words, there is a perceived threat that US grammar-focused faculties see practical language training courses connected to professions as taking away from a general liberal arts training and one of the causes of enrollment reduction in literature faculties. Additionally, some courses professors could question ESP teachers' qualifications (Tsou \& Chen, 2014), so treat them rather sceptically. Such a threatening tendency is being experienced around the world and should promote further talking across disciplines. All mentioned above might result in the lower status of teaching for non-philological students and constant ESP teachers' "identity struggles" (Tao \& Gao, 2018) as a necessity to build, or even "rebuild their [professional] identities" (Kanno \& Stuart, 2011).

It is against this background that most researchers explore the phenomenon of teacher identity, yet just a few ones consider the issue of ESP teacher identity as one of the keys to tertiary education enhancement, both internationally and locally. Hence, our paper aims to design a model of ideal ESP teacher identity within the reality-based higher education in Ukraine.

Our study seeks to answer the following research questions:

1. What features does ESP teacher identity imply?

2. In which categories do different social groups (ESP students, language, and subject teachers) construe the 'ideal' ESP teacher identity?

3. Are all the facets of the ESP teacher identity model valued the same within the three different relational contexts?

4. How do our findings correlate to other researchers' results?

\section{LITERATURE REVIEW}

Since its first mentioning by French writer Jean-Baptiste A. Karr in 1849, the notion of teacher identity has been described diversely in the educational landscape (Yazan \& Lindahl, 2020). As the teacher identity contexts are varied (e.g. personal, autobiographical, work-related, instructional, professional, etc. (Pennington \& Richards, 2016)), and often tend to change according to newly come students and/or the updated job requirements, this phenomenon is dynamic (Beauchamp \& Thomas, 2009, p.177) and always in flux (Pennington \& Richards, 2016, p.5), so it could be featured as constantly evolving. The concept of teacher identity was viewed in terms of "the unique set of characteristics associated with a particular individual relative to the perceptions and characteristics of others" (Pennington, 2015, p.16) and then was enriched with the idea of "a reflection of the context or activity in which the individual is situated" (Pennington \& 
Richards, 2016). The researchers inferred that teacher identity is about to link personal characteristics to the collective identity of a professional area.

As Liontas stated in his study Understanding Teacher Identity (Yazan \& Lindahl, 2020), the interpretations of the teacher identity concept involve various facets such as "individualsocial matter and communities of practice," "role enactment and role negotiation," "sense of self and relationship to the world", "self-positioning and positioning by others", "social affiliation and discourse interaction", or what Gee has called "affinities" (Gee, 2001), as well as "cognition and emotion", and "agency change and subjectivity". The notion of "occupational identity" is also one of the constituents of the identity framework. In Vondracek's studies (Vondracek et al, 1995; Vondracek \& Skorikov, 1997) the factor of self-readiness for would-be career decision-making forms the occupational identity domain. Similar to the initial concept of teacher identity, the notion of occupational identity as its constituent has also been defined diversely. For instance, Ireri's team definition of occupational identity as "a complex developmental process involving the interaction of personality, age and other related factors" (Ireri et al, 2013, p.88) hardly sheds light on the correlation between attitude to work versus age and gender of Kenyan university freshmen, and as a result, makes the idea of occupational identity rather vague. Richards (2012) does not define the teacher identity context itself but identifies ten dimensions which are the core in language teaching. Accordingly, it is affirmed that teacher identity nature is multifaceted due to the complicated interaction of various factors (Beijaard et al, 2004).

Drawing on Pennington's findings (2015), Tao and Gao (2018, p.3) attempted to build a model of ESP teacher identity (Figure 1). They adapted Pennington's concepts of local and global frames' influence on teacher identity formation and focused on contextual frames due to "a greater effect on teacher identity" (Tao \& Gao, 2018, p.3) of the former. The researchers delineated Pennington's local frame into the institutional and societal ones, following Varghese's team investigation layout (Varghese et al, 2005). Then, they refined the model with professional development and work experience facets, leaving without changes a professional layer, elaborated by Pennington. All the made replacements were due to limited relevance of their study.

Against this background, Sachs observed that "teacher identity is not something that is fixed nor is it imposed; rather it is negotiated through experience and the sense that is made of that experience" (Sachs, 2005, p.15). Pennington and Richards (2016) synthesized teacher identity competences (Foundational and Advanced) and illustrated factors that influence their development. The researchers worked out such a scheme when the synthesis of Foundation Competences (language-related identity, disciplinary identity, context-related identity, student and self-knowledge, and awareness) and Advanced Competences (community membership and the concepts of "knowledge into practice", and "practice into knowledge") make the desired outcome of creating language teacher identity (Pennington \& Richards, 2016).

In the project of Taylor's team (2013) teacher identity was investigated from a new perspective. The researchers addressed the need to explore the relationship between identity perception and academic achievements. Profound was the comparison of learning and teaching English as L2 and mathematics through online questionnaires of three respondent groups from four European countries. The project emphasized practical significance of encouraging identity development in a FL classroom and declared personally relevant learning and teaching environments. It is the first study in which the problem of low student motivation is linked to unidentified L2 teacher 
identity. The cross-sectional European study conducted by Taylor's research team (2013) attempted to generalize the results with the potential to influence educational policy globally.



An adapted model of ESP teacher identity (Tao \& Gao, 2018, p.3)

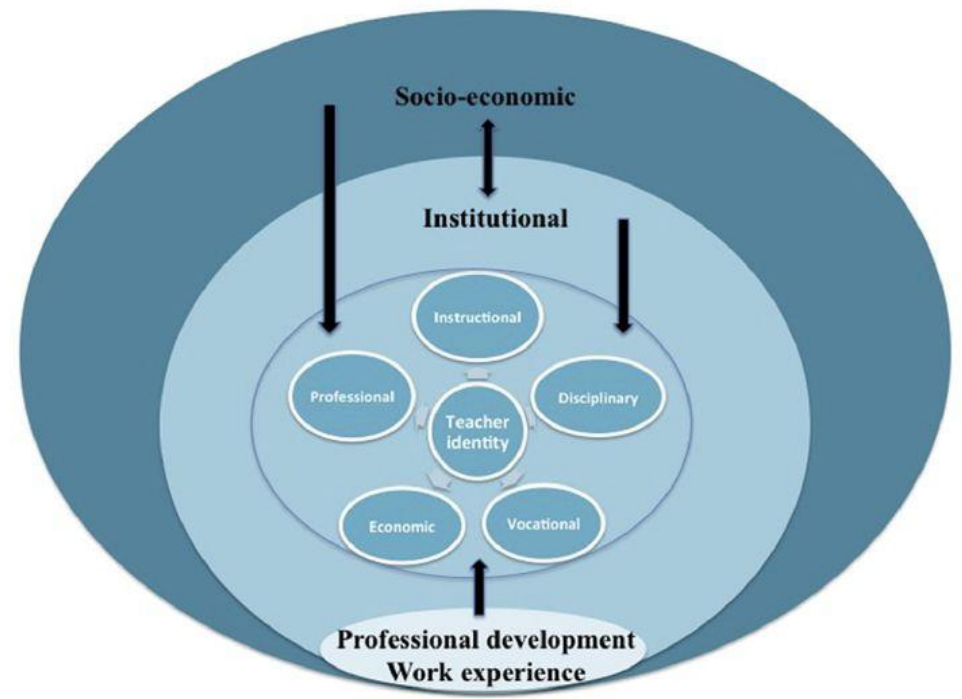

A refined model of ESP teacher identity (Tao \& Gao, 2018, p.11)

Fig. 1 The adapted and refined models of ESP teacher identity 
As shown, much research has been devoted to the issue of teacher identity or language teacher identity development, yet quite a few studies construe an ESP teacher model beneficial for successful in-class work and motivation enhancement of both students and staff. While the above-mentioned studies have all contributed useful insights into the topic, hardly any research has offered an empirical evaluation of the ESP teacher identity model through open- and closed-ended surveys within different relational contexts - ESP students, language and subject teachers.

\section{MATERIALS AND METHODS}

To conduct research, we applied the observation method, collection and analysis of open-ended and close-ended questionnaires' data, and statistical methods for ranking data. In particular, we collected and analyzed open-ended and close-ended questionnaires' data and applied the Likert scale statistical method for its ranking in a case study. A case was designing a model of "ideal" ESP teacher identity, and an analysis unit was ranking categories of ESP teacher identity simulated through a two-stage questionnaire.

\section{PARTICIPANTS AND SETTING}

Against this background, we conducted a case study aimed at designing a model of ideal ESP teacher identity through questioning 36 participants - 15 senior ESP students (years 3 and 4), 15 language teachers and 6 content teachers of Computer Science and Cybernetics Faculty at Taras Shevchenko National University of Kyiv, Ukraine. In our study, by "language teachers" we mean GE practitioners and by "content teachers" - the lecturers teaching the major courses at the Cybernetics faculty.

The study encompassed 3 stages:

1. opened-ended questionnaire;

2. closed-ended questionnaire;

3. cross-analysis of data output and modelling the 'ideal' ESP teacher identity.

\section{RESULTS AND DATA ANALYSIS}

Firstly, we divided the respondents into three research groups - Research Group 1 (RG 1) involved senior students, Research Group 2 (RG 2) - language teachers, and Research Group 3 (RG 3) - subject teachers. The participants answered the straightforward question "What, in your opinion, should an ideal ESP teacher be?" We targeted to pose the respondents an easily understood question to answer which would not take up much time and effort. There were no restrictions as to one response only. The respondents were free to express themselves in as many choices as they would prefer. Thorough scanning of the collected responses enabled us to group them in 5 categories - professional knowledge, work experience in the related field of knowledge (in our research it is IT), individual features, foreign language competence, and methods of teaching (Table 1). 
Table 1 Most common answer choices of RG 1-3 respondents in the open-ended questionnaire

\begin{tabular}{|c|c|c|c|}
\hline $\begin{array}{l}\text { Response } \\
\text { categories }\end{array}$ & RG 1 & RG 2 & RG 3 \\
\hline $\begin{array}{l}\text { Professional } \\
\text { knowledge }\end{array}$ & $\begin{array}{l}\text { Profound subject- } \\
\text { matter knowledge; } \\
\text { highly qualified } \\
\text { teacher. }\end{array}$ & $\begin{array}{l}\text { Subject competence; } \\
\text { linguistic intelligence. }\end{array}$ & $\begin{array}{l}\text { Subject specific skills; } \\
\text { subject-related } \\
\text { research experience. }\end{array}$ \\
\hline $\begin{array}{l}\text { Teaching } \\
\text { methods }\end{array}$ & $\begin{array}{l}\text { Interesting classroom } \\
\text { activities; } \\
\text { the ease of information } \\
\text { rendering; } \\
\text { teacher-student } \\
\text { collaboration. }\end{array}$ & $\begin{array}{l}\text { Teaching flexibility; } \\
\text { continuous } \\
\text { development of } \\
\text { training materials; } \\
\text { digitalization of } \\
\text { teaching. }\end{array}$ & $\begin{array}{l}\text { In-class activities to } \\
\text { make students more } \\
\text { engaged; } \\
\text { compilation of } \\
\text { teaching strategies and } \\
\text { approaches. }\end{array}$ \\
\hline $\begin{array}{l}\text { Individual } \\
\text { features }\end{array}$ & $\begin{array}{l}\text { Communicativeness; } \\
\text { enthusiasm; } \\
\text { sense of humour. }\end{array}$ & $\begin{array}{l}\text { Fairness; } \\
\text { keen interest in } \\
\text { students' needs; } \\
\text { encouragement. }\end{array}$ & $\begin{array}{l}\text { Reliability; } \\
\text { communicativeness; } \\
\text { strictness. }\end{array}$ \\
\hline $\begin{array}{l}\text { Foreign language } \\
\text { competence }\end{array}$ & $\begin{array}{l}\text { Fluent L2 speaker; } \\
\text { experienced in } \\
\text { communicating with } \\
\text { native speakers. }\end{array}$ & $\begin{array}{l}\text { An advanced L2 } \\
\text { speaker; } \\
\text { a professional EL } \\
\text { expert. }\end{array}$ & $\begin{array}{l}\text { FL knowledge that is } \\
\text { sufficient for scientific } \\
\text { literature } \\
\text { comprehension. }\end{array}$ \\
\hline Work experience & $\begin{array}{l}\text { Some IT field } \\
\text { experience; } \\
\text { knowledge of } \\
\text { technologies. }\end{array}$ & $\begin{array}{l}\text { Pedagogical working } \\
\text { background; } \\
\text { computer-based } \\
\text { training strategies. }\end{array}$ & $\begin{array}{l}\text { Desirable but not } \\
\text { essential subject- } \\
\text { related work } \\
\text { experience. }\end{array}$ \\
\hline
\end{tabular}

Table 1 reveals the top most frequent and common open-ended questionnaire responses of RG 1-3 respondents to the question "What, in your opinion, an ideal ESP teacher should be?" As the maximum number of answer choices was 5 and the minimum - 1 (only one respondent gave a single statement response - content teacher who wrote that it is "the student audience feeling an ideal ESP teacher needs to possess"), we chose on average 2-3 most frequent choices and included them in each table cell.

Then, we processed the collected multiple responses of each research group in MS Excel. Table 2 reveals the five response categories significantly loading onto the factors following the Likert rating scale. 
Table 2 Results on the open-ended questionnaire answer interpretation into response categories

("prof" - professional knowledge; "fl" - foreign language competence; "mt" - teaching methods; "ind" - individual features; "exp" - work experience

\begin{tabular}{|c|c|c|c|c|c|}
\hline \multirow{2}{*}{$\begin{array}{l}\text { Response } \\
\text { categories }\end{array}$} & \multicolumn{5}{|c|}{ Category of significance } \\
\hline & $\begin{array}{c}\text { most } \\
\text { significant }\end{array}$ & significant & $\begin{array}{l}\text { moderately } \\
\text { significant }\end{array}$ & $\begin{array}{c}\text { slightly } \\
\text { significant }\end{array}$ & not significant \\
\hline \multicolumn{6}{|c|}{ RG 1} \\
\hline 1 & prof & prof & $\mathrm{mt}$ & $\mathrm{mt}$ & ind \\
\hline 2 & prof & prof & $\mathrm{mt}$ & $\mathrm{fl}$ & ind \\
\hline 3 & ind & ind & prof & ind & $\mathrm{fl}$ \\
\hline 4 & $\mathrm{mt}$ & ind & prof & ind & ind \\
\hline 5 & prof & $\exp$ & $\exp$ & $\mathrm{mt}$ & $\exp$ \\
\hline 6 & $\exp$ & $\mathrm{fl}$ & $\mathrm{fl}$ & ind & ind \\
\hline 7 & $\mathrm{mt}$ & $\exp$ & $\mathrm{mt}$ & $\mathrm{mt}$ & ind \\
\hline 8 & $\exp$ & prof & $\mathrm{fl}$ & $\exp$ & $\mathrm{mt}$ \\
\hline 9 & ind & $\mathrm{mt}$ & prof & ind & $\mathrm{mt}$ \\
\hline 10 & prof & ind & ind & prof & ind \\
\hline 11 & $\mathrm{mt}$ & ind & $\mathrm{mt}$ & prof & $\mathrm{fl}$ \\
\hline 12 & $\mathrm{mt}$ & $\mathrm{mt}$ & ind & $\mathrm{mt}$ & ind \\
\hline 13 & prof & prof & prof & prof & $\mathrm{fl}$ \\
\hline 14 & prof & ind & $\mathrm{mt}$ & $\mathrm{fl}$ & ind \\
\hline 15 & prof & $\mathrm{fl}$ & ind & $\mathrm{mt}$ & prof \\
\hline \multicolumn{6}{|c|}{ RG 2} \\
\hline 1 & ind & ind & ind & ind & ind \\
\hline 2 & $\mathrm{fl}$ & ind & ind & ind & ind \\
\hline 3 & $\mathrm{fl}$ & $\exp$ & ind & ind & $\mathrm{mt}$ \\
\hline 4 & $\mathrm{fl}$ & $\mathrm{mt}$ & $\mathrm{mt}$ & ind & ind \\
\hline 5 & ind & $\mathrm{fl}$ & ind & ind & ind \\
\hline 6 & $\mathrm{mt}$ & $\mathrm{mt}$ & ind & $\mathrm{fl}$ & $\mathrm{fl}$ \\
\hline 7 & $\mathrm{fl}$ & ind & $\mathrm{fl}$ & ind & ind \\
\hline 8 & $\mathrm{fl}$ & ind & exp & $\mathrm{mt}$ & $\mathrm{mt}$ \\
\hline 9 & prof & $\exp$ & $\exp$ & $\mathrm{fl}$ & ind \\
\hline 10 & $\mathrm{fl}$ & ind & ind & ind & ind \\
\hline 11 & $\mathrm{mt}$ & $\mathrm{fl}$ & $\mathrm{fl}$ & ind & ind \\
\hline 12 & $\mathrm{fl}$ & ind & ind & $\mathrm{mt}$ & ind \\
\hline 13 & prof & ind & ind & ind & $\mathrm{fl}$ \\
\hline 14 & $\mathrm{fl}$ & $\mathrm{mt}$ & $\mathrm{mt}$ & prof & ind \\
\hline 15 & ind & prof & $\mathrm{mt}$ & $\exp$ & prof \\
\hline \multicolumn{6}{|c|}{ RG 3} \\
\hline 1 & prof & $\exp$ & $\exp$ & ind & $\mathrm{mt}$ \\
\hline 2 & prof & $\mathrm{fl}$ & $\mathrm{mt}$ & ind & $\exp$ \\
\hline 3 & prof & ind & ind & $\mathrm{mt}$ & $\mathrm{fl}$ \\
\hline 4 & ind & ind & ind & $\mathrm{mt}$ & ind \\
\hline 5 & prof & $\mathrm{fl}$ & $\mathrm{mt}$ & ind & ind \\
\hline 6 & ind & ind & $\mathrm{fl}$ & $\mathrm{mt}$ & prof \\
\hline
\end{tabular}


Next, we interpreted the obtained response categories quantitatively, assigning each response a point value from 0 as "not significant" to 4 as "most significant" (Table 3 ).

Table 3 Identifying categories of significance on the sum of values

\begin{tabular}{|c|c|c|c|c|c|c|c|}
\hline \multirow[b]{2}{*}{$\begin{array}{l}\text { Response } \\
\text { categories }\end{array}$} & \multicolumn{5}{|c|}{ Category of significance } & \multirow[b]{2}{*}{ Value } & \multirow[b]{2}{*}{$\%$} \\
\hline & \begin{tabular}{|c|}
$4-$ \\
most \\
significant \\
\end{tabular} & $\begin{array}{c}3- \\
\text { significant }\end{array}$ & $\begin{array}{c}2- \\
\text { moderately } \\
\text { significant }\end{array}$ & $\begin{array}{c}1- \\
\text { slightly } \\
\text { significant } \\
\end{array}$ & \begin{tabular}{|c|}
$0-$ \\
not \\
significant \\
\end{tabular} & & \\
\hline \multicolumn{8}{|c|}{ RG 1} \\
\hline prof & 7 & 4 & 4 & 3 & 1 & 51 & 34,0 \\
\hline $\mathrm{mt}$ & 4 & 2 & 5 & 5 & 2 & 37 & 24,7 \\
\hline ind & 2 & 5 & 3 & 4 & 8 & 33 & 22,0 \\
\hline $\mathrm{fl}$ & 0 & 2 & 2 & 2 & 3 & 12 & 8,0 \\
\hline $\exp$ & 2 & 2 & 1 & 1 & 1 & 17 & 11,3 \\
\hline \multicolumn{8}{|c|}{ RG 2} \\
\hline prof & 2 & 1 & 0 & 1 & 1 & 12 & 8,0 \\
\hline $\mathrm{mt}$ & 2 & 3 & 3 & 2 & 2 & 25 & 16,7 \\
\hline ind & 3 & 7 & 8 & 9 & 10 & 58 & 38,7 \\
\hline $\mathrm{fl}$ & 8 & 2 & 2 & 2 & 2 & 44 & 29,3 \\
\hline $\exp$ & 0 & 2 & 2 & 1 & 0 & 11 & 7,3 \\
\hline \multicolumn{8}{|c|}{ RG 3} \\
\hline prof & 4 & 0 & 0 & 0 & 1 & 16 & 26,7 \\
\hline $\mathrm{mt}$ & 0 & 0 & 2 & 3 & 1 & 7 & 11,7 \\
\hline ind & 2 & 3 & 2 & 3 & 2 & 24 & 40,0 \\
\hline $\mathrm{fl}$ & 0 & 2 & 1 & 0 & 1 & 8 & 13,3 \\
\hline exp & 0 & 1 & 1 & 0 & 1 & 5 & 8,3 \\
\hline
\end{tabular}

Within the dataset, we designed a rank of values, which appeared to be different for the research groups. Table 3 shows that both language and subject teachers valued the most "individual features" (the sums of points are 58 and 24) and the least "work experience" (11 and 5 correspondingly), whereas the surveyed students estimated correspondingly "professional knowledge" (51) and "foreign language competence" (12).

Since the open-ended questionnaire outputs provided us with the "scope for greater exploration" (Brace, 2008, p.2), we targeted further expertise through the closed-ended questionnaire. We specified the range of five survey questions, i.e. gave the respondents the option to select from the defined list of choices - from "strongly agree" to "strongly disagree". Table 4 represents the closed-ended questionnaire layout. 
Table 4 Closed-ended questionnaire layout

\begin{tabular}{|c|c|}
\hline Survey questions & Rating scale \\
\hline $\begin{array}{l}\text { 1. Do you think that individual characteristics (e.g. communicativeness, } \\
\text { humour, creativeness, patience, responsibility, etc) are most } \\
\text { important for an ESP teacher? }\end{array}$ & \multirow{5}{*}{$\begin{array}{l}\square \text { Strongly } \\
\text { agree } \\
\square \text { Agree } \\
\square \text { Not sure } \\
\square \text { Disagree } \\
\square \text { Strongly } \\
\text { disagree }\end{array}$} \\
\hline $\begin{array}{l}\text { 2. Do you think that professional knowledge (e.g. knowledge of } \\
\text { technologies, specific terms, vocabulary, etc) is most important for an } \\
\text { ESP teacher? }\end{array}$ & \\
\hline $\begin{array}{l}\text { 3. Do you think that work experience (e.g. previous employment and } \\
\text { skills in the IT field, etc) is most important for an ESP teacher? }\end{array}$ & \\
\hline $\begin{array}{l}\text { 4. Do you think that a method of teaching (e.g. clear explanation of the } \\
\text { topic, encouragement of students' discussion and teamwork, etc) is } \\
\text { most important for an ESP teacher? }\end{array}$ & \\
\hline $\begin{array}{l}\text { 5. Do you think that English language fluency (i.e. when a teacher } \\
\text { sounds natural in English) is most important for an ESP teacher? }\end{array}$ & \\
\hline
\end{tabular}

All the research participants completed the closed-ended questionnaire laid out in Google forms. The technical provision ensured accurate and complete recording of the questionnaire responses. The format of the questions was predetermined by the openended survey data entry. We applied the classic Likert 5-point response scale and calculated the sums of points (Value) aimed at estimating the significance of each category. The question types were not varied and the rating scale remained the same for each question aimed at simplifying the question perception and comprehension, and on the other hand, ensuring a more accurate assessment of the respondents' opinions. All the responses were again processed in MS Excel. The tailored survey questions provided the information which was sought (Table 5).

Table 5 Closed-ended questionnaire layout data

\begin{tabular}{|c|c|c|c|c|c|c|}
\hline \multirow{2}{*}{$\begin{array}{l}\text { Research } \\
\text { group }\end{array}$} & \multirow{2}{*}{ Scale } & \multicolumn{5}{|c|}{ Survey questions } \\
\hline & & q1 (ind) & $\mathrm{q} 2$ (prof) & $\mathrm{q} 3(\exp )$ & $\mathrm{q} 4(\mathrm{mt})$ & $\mathrm{q} 5(\mathrm{fl})$ \\
\hline \multirow{6}{*}{ RG1 } & $2-$ strongly agree & 29,2 & 50 & 20,8 & 47,7 & 25 \\
\hline & 1 - agree & 54,2 & 30,3 & 50 & 46,7 & 45,8 \\
\hline & $0-$ not sure & 16,6 & 15,5 & 20,9 & 5,6 & 20,8 \\
\hline & -1 - disagree & 0 & 0 & 8,3 & 0 & 4,2 \\
\hline & $-2-$ strongly disagree & 0 & 4,2 & 0 & 0 & 4,2 \\
\hline & Value & 112,6 & 121,9 & 83,3 & 142,1 & 83,2 \\
\hline \multirow{6}{*}{$\begin{array}{c}\text { RG2 } \\
+ \\
\text { RG3 }\end{array}$} & $2-$ strongly agree & 43,8 & 70 & 12,5 & 67 & 37,5 \\
\hline & 1 - agree & 37,5 & 15,5 & 62,5 & 33 & 50 \\
\hline & $0-$ not sure & 18,8 & 14,5 & 12,5 & 0 & 12,5 \\
\hline & -1 - disagree & 0 & 0 & 12,5 & 0 & 0 \\
\hline & $-2-$ strongly disagree & 0 & 0 & 0 & 0 & 0 \\
\hline & Value & 125,1 & 155,5 & 75 & 167 & 125 \\
\hline \multicolumn{2}{|r|}{ Total } & 237,7 & 277,4 & 158,3 & 309,1 & 208,2 \\
\hline \multicolumn{2}{|r|}{$\%$} & 20,0 & 23,3 & 13,3 & 26,0 & 17,5 \\
\hline
\end{tabular}


As the ranges of values in RG 2 and RG 3 responses were similar to each other, we combined this data into one group, which is set out in the RG2+RG3 column of Table 5. As shown, the obtained data on the closed-ended questionnaire diminished the differences between the constituents' significance in the ESP teacher identity image. Although the research data was obtained from three different social groups of respondents whose opinions varied at the first stage of the questionnaire, their closed-ended responses specified and balanced all the facets of the model. Based on the sums of the values (Total in Table 5), the designed common model of the "ideal" ESP teacher identity implied the following categories (from the most significant to the least): methods of teaching $\rightarrow$ professional knowledge $\rightarrow$ individual features $\rightarrow$ foreign language competence $\rightarrow$ work experience $(26 \% \rightarrow 23 \% \rightarrow 20 \% \rightarrow 18 \% \rightarrow 13 \%$ correspondingly). Interestingly, the difference between the most and the least significant categories is double (26\% versus $13 \%)$. Both students and teachers estimated the most training techniques and methods combined with professional knowledge and considered work experience less important for a teacher who is imposed to equip students with professional skills and competitive knowledge in the ESP classroom.

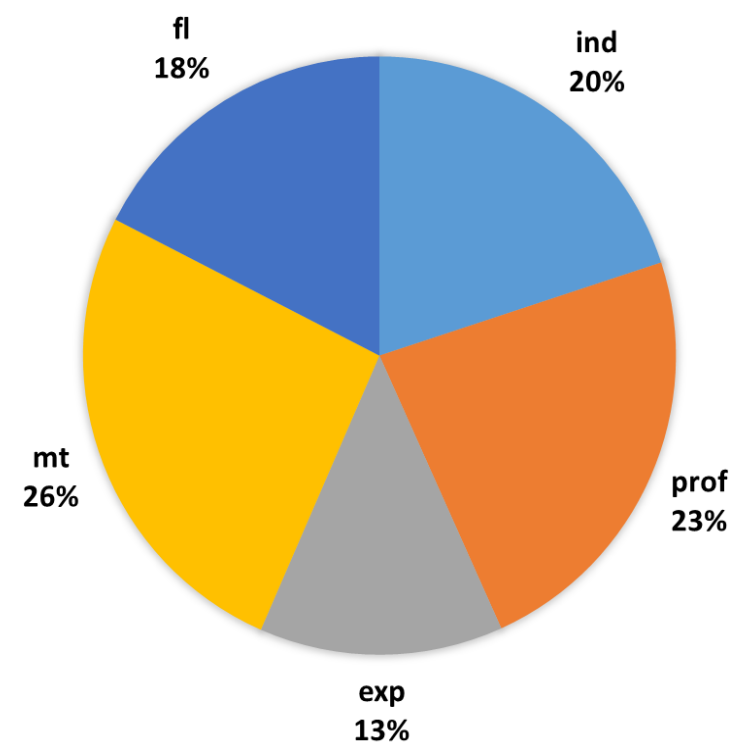

Fig. 2 The multi-faceted model of an 'ideal' ESP teacher

\section{DiSCUSSION AND CONCLUSIONS}

Following Tao and Gao (2018), we also examined the teacher identity phenomenon and built a model of ESP teacher identity. In Research Question 1, we targeted to identify the features that ESP teacher identity implies. Instead of adapting Pennington's model of TESOL teacher identity frames (2015) and working out a refined framework, we constructed our own, inter-personally determined model relevant to the Ukrainian academic setting. 
Following Research Question 2, we interviewed three different groups, ESP students, language and subject teachers, and designed a simpler but more exact model of ESP teacher identity's priorities influenced by Pennington's (2015), and Tao and Gao's (2018) much more general global, socio-economic and institutional contexts. As summarized by Tao and Gao (2018), professional development ensures meaningful work of teachers and foregrounds the elaborated model. Similarly, we applied the idea that L2 teaching methodology and knowledge in ESP related fields make ESP teacher identity, but we made a deeper investigation on the assumption of a two-stage survey of 36 respondents within three social groups (contrary to 8 ESP teacher respondents in Tao and Gao's study). Similar to Pennington and Richards' study (2016) we also considered the role of EL teacher identity crucial in both ESP teaching and learning. Additionally, our result echoes the findings of Taylor's cross-sectional European study (2013) that ESP student and teacher identity perceptions are closely related. Different from the other research is the specification of the teacher identity concept to 5 exact facets (methods of teaching, professional knowledge, individual features, foreign language competence, work experience) from three relational contexts - ESP students, language teachers, and subject teachers. The investigation of Research Question 3 shows that the participants have valued the five facets differently. Discrepancies in ESP teacher constituents perception of the survey respondents correlate to the other topic-related research (Research Question 4) and prove that struggles are inevitable and require adjustments, as a prerequisite for evolution (Pennington \& Richards, 2016, p.5). The standardized questionnaire format allowed interpreting the obtained data accurately, enabled us to achieve the study objective and answer all the research questions. Such findings do not contradict other researches' data and prove the relevance of our model.

Considering the aforementioned discussion, a pedagogical repertoire of an "ideal" ESP teacher is likely to comprise such skills that enable a teacher to convey contentbased knowledge for students' easy comprehension and productive application. Such a teacher seems to be eager to train on the spot, he/she could hardly overload students with excessive hand-outs, and looks like an engaging and engaged L2 proficient mediator with some content-matter practical experience in the related field of knowledge.

With the growth of IT, Cybernetics and Computer Sciences enrolment in the Ukrainian tertiary education system, institutions and faculties administrations are urged to redesign the specialty curricula, particularly ESP. While striving for the best student academic results in major courses and their future successful employability, it is necessary to demarginalize the status of ESP courses from optional to obligatory not only in Ukraine but also worldwide. Within the globalized international scenario of the $21^{\text {st }}$ century, it is no more relevant to consider ESP as a threat but, on the contrary, one of the most productive teaching approaches to enable students to acquire high-level knowledge and skills to serve them personally and professionally.

Hereby, we believe that consideration of the ESP teacher identity domains identified in our research could aim to develop the collective identity of self and profession. Not less importantly, it is to focus on the learner's identity as a "starting point" or "a primary resource" (Miller, 2009, p.178) for FL teaching as a whole and students' disciplinary literacy development in particular. The built model boosts much-needed further investigation of a set of training techniques and practices to best fit the needs of ESP teachers' self-professional development and graduates' employability. 


\section{LIMITATIONS}

There might be some limitations to this research. From a practical standpoint, the worked-out model of the ESP teacher simulated from perceptions of three different groups could be stable and relevant inside the academic context of Ukraine, as the students and staff of Taras Shevchenko University of Kyiv were surveyed. The relatively small participants' quantity does not allow generalizing the research results to other educational environments.

\section{REFERENCES}

Beauchamp, C. \& Thomas, L. (2009). Understanding Teacher Identity: An overview of issues in the literature and implications for teacher education. Cambridge Journal of Education, 39(2), 175-189. doi:10.1080/03057640902902252.

Beijaard, D., Meijer, P. \& Verloop, N. (2004). Reconsidering Research on Teachers' Professional Identity. Teaching and Teacher Education, 20(2), 107-128. doi:10.1016/j.tate.2003.07.001.

Bolton, K., \& Kuteeva, M. (2012). English as an Academic Language at a Swedish University: Parallel language use and the 'threat' of English. Journal of Multilingual and Multicultural Development, 33(5), 429-447. doi:10.1080/01434632.2012.670241.

Borg, S. (2006). The Distinctive Characteristics of Foreign Language Teachers. Language Teaching Research, 10(1), 3-31. doi:10.1191/13621688061r182oa.

Brace, I. (2008). Questionnaire Design: How to Plan, Structure and Write Survey Material for Effective Market Research. Kogan Page Publishers.

Cheng, A., \& Anthony, L. (2014). ESP Research in Asia: Guest editorial. English for Specific Purposes, 33, 1-3. doi:10.1016/j.esp.2013.07.002.

Gee, J. P. (2001). Identity as an Analytic Lens for Research in Education. Review of Research in Education, 25(1), 99-125.

Ireri, A., Thuku, P., \& Karugu, N. (2013). Relationship Among Occupational Identity, Attitude toward Work, Age and Gender of First Year University Students in Kenya. Psychology and Social Behavior Research, 1(4), 88-97. doi:10.12966/psbr.10.01.2013.

Kanno, Y., \& Stuart, C. (2011). Learning to Become a Second Language Teacher: Identities-in-Practice. The Modern Language Journal, 95(2), 236-252. doi:10.1111/j.1540-4781.2011.01178.x.

Long, M., \& Uzcinski, I. (2012). Evolution of Languages for Specific Purposes Programs in the United States: 1990-2011. Modern Language Journal, 96(1), 173-189. doi:10.1111/j.1540-4781.2012.01303.x.

Miller, J. (2009). Teacher Identity. In: Burns A. and Richards J. C. (eds). The Cambridge Guide to Second Language Teacher Education, 172-181.

Pennington, M. C. (2015). Teacher Identity in TESOL: A Frames Perspective. In: Cheung Y. L., Said S. B., and Park K. (eds). Teacher Identity and Development in Applied Linguistics: Current Trends and Perspectives, 16-30.

Pennington, M. C., \& Richards, J. C. (2016). Teacher Identity in Language Teaching: Integrating Personal, Contextual, and Professional Factors. RELC Journal, 47(1), 119. doi:10.1177/0033688216631219.

Richards, J. C. (2012). Competence and Performance in Language Teaching. The Cambridge Guide to Pedagogy and Practice in Second Language Teaching, 46-59. 
Sachs, J. (2005). Teacher Education and the Development of Professional Identity: Learning to Be a Teacher. In: Denicolo, P. \& Kompf, M. (eds). Connecting Policy and Practice: Challenges for Teaching and Learning in Schools and Universities, 5-12.

Sánchez-López, L., Long, M., \& Lafford, B. (2014). Research Interests and Needs in Languages for Specific Purposes in Higher Education in the United States: A survey study. Paper presented at the Second International Symposium on Languages for Specific Purposes, Boulder, CO, April 17-19.

Tao, J. (Tracy), \& Gao, X. (Andy). (2018). Identity Constructions of ESP Teachers in a Chinese University. English for Specific Purposes, 49, 1-13. doi:10.1016/j.esp.2017. 09.003.

Taylor, F., Busse, V., Gagova, L., Marsden, E. \& Roosken, B. (2013). Identity in Foreign Language Learning and Teaching: Why Listening to Our Students' and Teachers' Voices Really Matters. ELT Research Papers, The British Council, The University of York, London.

Tsou, W., \& Chen, F. (2014). ESP Program Evaluation Framework: Description and application to a Taiwanese university ESP program. English for Specific Purposes, 33(1), 39-53. doi:10.1016/j.esp.2013.07.008.

Varghese, M., Morgan, B., Johnston, B., \& Johnston, K. (2005). Theorizing Language Teacher Identity: Three Perspectives and Beyond. Journal of Language, Identity, and Education, 4(1), 21-44.

Vondracek, F. W., \& Skorikov, V. B. (1997). Leisure, School, and Work Activity Preferences and Their Role in Vocational Identity Development. Career Development Quarterly, 45, 322-334.

Vondracek, F. W., Schulenberg, J., Skorikoc, V., Gillespie, L. K., \& Wahlheim, C. (1995). The Relationship of Identity Status to Career Indecision During Adolescence. Journal of Adolescence, 18, 17-29.

Wu, H., \& Badger, R. G. (2009). In a Strange and Uncharted Land: ESP teachers' strategies for dealing with unpredicted problems in subject knowledge during class. English for Specific Purposes, 28(1), 19-32. doi:10.1016/j.esp.2008.09.003.

Yazan, B. \& Lindahl, K. (2020). Language Teacher Identity in TESOL: Teacher Education and Practice as Identity Work. New York: Routledge. doi:10.4324/ 9780429342875. 